\title{
Marcin Wasilewski
}

Uniwersytet Łódzki

\section{Pedagogika helleńska w artykułach naukowych i popularnonaukowych Stanisława Schneidra (1858-1917)}

Stanisław Schneider, lwowianin, hellenista, członek-korespondent Akademii Umiejętności w Krakowie, jest dziś postacią mało znaną nawet wśród historyków myśli pedagogicznej. Nie notuje go specjalistyczny Słownik biograficzny polskiej historii wychowania ${ }^{1}$, nie wspominając już o znacznie bardziej popularnych słownikach i encyklopediach pedagogicznych. A przecież dorobek Schneidra dostrzegał wybitny historyk literatury starogreckiej Tadeusz Sinko ${ }^{2}$, specjalistyczne prace lwowskiego uczonego odnotowywał także Stanisław Kot ${ }^{3}$. Schneidrowi nie dane było dożyć wolnej Polski, gdzie zapewne znalazłby należne mu miejsce w strukturach uniwersyteckich. Zmarł przedwcześnie na przewlekłą chorobę serca ${ }^{4}$.

S. Schneider należy do wąskiego grona polskich uczonych (obok m.in. Antoniego Danysza), którym bliska była pedagogika helleńska - myśl pedagogiczna antycznej Grecji. Z licznych artykułów lwowskiego uczonego warto przywołać te, które są szczególnie ważne z punktu widzenia metahistorii myśli pedagogicznej. Po pierwsze, zwrócić należy uwagę na studium Schneidra z tomu XXVI „Rozpraw Wydziału Filologicznego Akademii Umiejętności w Krakowie” z roku 1896 pt. Czy madrości i cnoty można nauczyć? (bezimienna rozprawka $z$ połowy w. $V$. przed $C h r$.); praca ta została także opublikowana w postaci oddzielnej odbitki. Drugim, bardzo obszernym artykułem zasługującym na pamięć jest rozprawa Studya filologiczne nad rozwojem oświaty greckiej $w$ V wie-

${ }^{1}$ Stownik biograficzny polskiej historii wychowania, red. A Meissner, W. Szulakiewicz, Toruń 2008.

${ }^{2}$ T. Sinko, Literatura grecka, t. 1, cz. 2, Literatura klasyczna (w. V-IV przed Chr.), Kraków 1932, s. 153.

${ }^{3}$ S. Kot, Historia wychowania, t. 1, Od starożytnej Grecji do połowy wieku XVIII, Warszawa 1996 (reprint edycji z roku 1934), s. 45.

${ }^{4}$ A. Śródka, P. Szczawiński, Biogramy uczonych polskich: materiaty o życiu $i$ działalności członków AU w Krakowie, TNW, PAU, PAN, cz. 1, z. 3, Wrocław 1985. 
ku przed Chr., która również wydana została w „Rozprawach Wydziału Filologicznego Akademii Umiejętności w Krakowie”, w tomie XXXIII z roku 1901, i także edytowana była na oddzielnej odbitce. Trzecim wreszcie studium S. Schneidra, na które warto zwrócić uwagę, jest dwuczęściowy artykuł popularnonaukowy z 36 numeru „Przewodnika Naukowego i Literackiego” z roku 1908 pt. Sofiści a oświata helleńska.

Dorobek lwowskiego hellenisty w zakresie badań nad pedagogiką starogrecką zasługuje na zainteresowanie ze strony historyków myśli pedagogicznej i dogłębne zbadanie. Poniżej postaram się jedynie wskazać na poruszane przez Schneidra wątki tematyczne, ich historiozoficzną osnowę, warsztat historiograficzny oraz na oryginalne i śmiałe tezy stawiane przez tego uczonego na podstawie podjętych przez niego badań.

Jeśli spojrzeć na dorobek S. Schneidera z najszerszej perspektywy historiozoficznej, to w sposobie rozumienia greckiej myśli filozoficznej kontynuuje ono linię interpretacyjną wyznaczoną przez wielkie dzieła Hegla, Grote'a i Gomperza. Lwowski uczony, podobnie jak jego wielcy poprzednicy, przekonany jest o doniosłej (i pozytywnej) roli, jaką odegrali sofiści w dziejach Hellady. Schneider pragnie zdjać odium nadane sofistyce przez Platona i Arystotelesa, polemizując - niejako przy okazji - z interpretacjami znakomitego polskiego historyka filozofii greckiej i platonika Stefana Pawlickiego ${ }^{5}$.

Pojęcie »oświaty greckiej (helleńskiej)« nie oznacza u Schneidra systemu edukacji, lecz »epokę odrodzenia i oświecenia w antycznej Grecji ${ }^{6}$. Mówiąc ściślej: epokę w dziejach Hellady analogiczną do epok odrodzenia i oświecenia w nowożytnej Europie. Jednakże greckie odrodzenie i oświecenie związane są nie tylko z powstaniem i rozwojem nauk, ale i przemianami na niwie edukacji. Ten właśnie konglomerat pojęć, zgodnie z duchem XIX-wiecznej jeszcze polszczyzny, określał Schneider jako »oświatę « ${ }^{7}$. O tej różnicy semantycznej warto pamiętać, bo w ciaggu ponad stu lat od opublikowania jego prac zmieniła się nie tylko ortografia i interpunkcja, ale i znaczenie wielu wyrazów, co może prowadzić do nieporozumień.

Jeśli idzie o warsztat historiograficzny, to był Schneider konsekwentnym zwolennikiem metody filologicznej, czyli analizy porównawczej terminów i fraz występujących w tekstach źródłowych. Znajomość greki i erudycja pozwalały mu doszukiwać się nierozpoznanych wcześniej filiacji i utajonych polemik między poglądami poszczególnych myślicieli, a co za tym idzie, stawiania

\footnotetext{
${ }^{5}$ S. Schneider, Sofiści, a oświata helleńska, „Przewodnik Naukowy i Literacki” 1908, XXXVI, s. 288.

${ }^{6} \mathrm{~S}$. Schneider, Studya filologiczne nad rozwojem oświaty greckiej $w$ V wieku przed Chr., Kraków 1901, s. 1-2; tenże, Sofiści, a oświata helleńska..., s. 178.

${ }^{7}$ Por.: K. Długosz-Kurczabowa, Wielki słownik etymologiczno-historyczny języka polskiego, Warszawa 2008, s. 648; A. Bańkowski, Etymologiczny stownik języka polskiego, t. 2, Warszawa 2000, s. 462.
} 
śmiałych i kontrowersyjnych tez. Z drugiej zaś strony, owo trzymanie się jedynie ściśle filologicznych podobieństw w niepełnych, a niekiedy wątpliwych i zachowanych fragmentarycznie tekstach źródłowych, może być narażone na zarzut arbitralności. W aspekcie diachronicznym obszar badań podjętych przez Schneidra obejmuje okres od końca VI do końca V wieku p.n.e. Postaciami granicznymi tej epoki w narracji lwowskiego hellenisty są Solon (u jej początków) i Sokrates u jej końca. Schneider poddaje swej wykładni oświaty greckiej kolejno: Solona, pitagorejczyków, Hippokratesa, orfików, Parmenidesa, Empedoklesa, Heraklita, Anaksagorasa, Protagorasa, Prodikosa, Gorgiasza, Hippiasza, Antyfonta, Herodota, Tukidydesa, Sofoklesa, Antystenesa i Sokratesa.

Niemal każda stronica u Schneidra przynosi oryginalną (i kontrowersyjną zarazem) interpretację. Jako przykład przytoczę fragmenty jego tekstów interesujące nie tylko dla historyka myśli pedagogicznej, ale i historyka edukacji. Pierwszy fragment pochodzi z artykułu popularnonaukowego, a więc pozbawionego aparatu naukowego:

Mamy ślady, że sekta pitagorejska opanowała w Atenach system edukacyjny rady w Areopagu, który zasadzał się na ciagłych a uciążliwych ćwiczeniach i długoletnim zaprawieniu od dziecka do uległości wobec nakazów, tudzież etycznych przepisów ${ }^{8}$.

Powyższa teza Schneidra ma charakter iście rewolucyjny, zmieniający nasze wyobrażenia o edukacji w początkach $\mathrm{V}$ wieku p.n.e. Aby zrozumieć, jakie ślady źródłowe lwowski badacz ma na myśli, sięgnijmy po cytat z jego wcześniejszej pracy o charakterze stricte naukowym, w której myśl ta jest rozwinięta:

System edukacyjny rady Areopagu nie jest nam wprawdzie znany w szczegółach, lecz z utyskiwań Prodykosa i wstrętu do niego Temistoklesa wnosić możemy, że się zasadzał na ciągłych a uciążliwych ćwiczeniach i długoletnim zaprawianiu dziecka do uległości wobec nakazów, tudzież etycznych przepisów. Hasłem dwóch szkół połączonych, pitagorejskiej oraz medycznej, pod czujną strażą Areopagu było: dosztukowywać i nadsztukowywać przyrodę przez urabianie

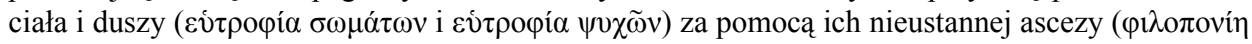
i $\varphi(\lambda o \psi v \chi i ́ \eta)$. Nie dziw tedy, że taka wychowawcza metoda wydała się demosowi ateńskiemu poprostu niemożliwą i że adeptów pedagogicznej rutyny pozbył się w końcu z państwa9 ${ }^{9}$.

Schneider na potwierdzenie powyższych tez przywołuje szereg świadectw źródłowych, m.in.: Politykę Arystotelesa, Tukidydesa, pseudoplatoński dialog Aksiochos, Temistoklesa Plutarcha oraz (domyślnie) Ustrój polityczny Aten Pseudo-Ksenofonta i Protagorasa Platona. W czasach, gdy Schneider pisał swe artykuły, powyższe źródła w większości nie były jeszcze przetłumaczone na język polski, lwowski hellenista stosowne miejsca przytaczał w aparacie nau-

\footnotetext{
${ }^{8}$ S. Schneider, Sofiści, a oświata helleńska.., s. 179.

${ }^{9} \mathrm{~S}$. Schneider, Studya filologiczne nad rozwojem oświaty greckiej $w$ V wieku przed Chr., s. $39-40$.
} 
kowym w greckim oryginale. Aby prześledzić jego tok rozumowania, przytoczę dla wygody te fragmenty w późniejszych przekładach.

Kluczowym tekstem na poparcie tez Schneidra jest fragment dialogu Aksiochos (p. 366-369), uważanego za ważne źródło do odtworzenia myśli Prodikosa. Sokrates relacjonuje tu (z pamięci) umierającemu Aksiochosowi pesymistyczne poglądy Prodikosa:

Czyż dziecko już w chwili narodzin nie płacze, rozpoczynając życie od smutku? [...] A dalej, gdy dojdzie do siódmego roku życia, gdy zniesie już liczne trudy dzieciństwa, powierza się je okrutnej władzy pedagogów, gramatystów i nauczycieli; gdy zaś podrośnie jeszcze - wszelkiego rodzaju biegłym, geometrom, nauczycielom sztuki wojennej i thumowi innych nauczycieli. Gdy zaś młodzieniec zostanie wpisany na listę efebów, przychodzi nań jeszcze gorszy strach: Liceum, Akademia i władza gimnazjarchów, rózgi i bezmiar nieszczęść. I tak cała młodość mija pod władzą owych nadzorców z Areopagu na mocy ustawy o wykształceniu (tłum. J. Gajda) ${ }^{10}$.

Rolę pomocniczą pełnią świadectwa o braku wykształcenia Temistoklesa. Odnośny tekst Tukidydesa (I 138) o mądrości słynnego ateńskiego wodza brzmi:

[...] Temistokles ze względu na wyjątkową siłę ducha, której najoczywistsze składał dowody, zasługiwał na większy podziw niż ktokolwiek inny: dzięki bowiem wrodzonemu talentowi, bez żadnych uprzednich czy późniejszych studiów, oceniał po krótkim zastanowieniu najtrafniej każdą aktualną sytuację i najlepiej przewidywał daleką przyszłość; równie jasno umiał wyłuszczyć to, z czym był obznajomiony, jak i trafnie osądzać to, co było mu obce ${ }^{11}$.

O specyficznej niechęci Temistoklesa do nauki pisze również $\mathrm{w}$ jego biografii Plutarch (Temistokles, par. 2,3):

[...] Temistokles z przykrością i niechętnie uczył się przedmiotów ogólnych, których celem było kształtowanie charakteru lub dostarczanie jakiejś przyjemności i elegancji wolno urodzonemu dziecku. W przedmiotach zaś, o których powiadano, że [służa] i rozumowi, i działalności politycznej był ponad wiek lekceważący, jakby ufając swym naturalnym zdolnościom ${ }^{12}$.

I wreszcie ostatni z kluczowych tekstów, fragment Ustroju politycznego Aten (par. 13) Pseudo-Ksenofonta:

Lud pozbawił tam [tzn. w Atenach - M.W.] znaczenia osoby uprawiające ćwiczenia gimnastyczne i zajmujące się muzyką, nie uważając tych zajęć za właściwe, ponieważ wiedział, że sam nie może im sprostać ${ }^{13}$.

${ }^{10}$ J. Gajda, Sofiści, Warszawa 1989, s. 257.

${ }^{11}$ Tukidydes, Wojna peloponeska, z języka greckiego przełożył, przedmową i przypisami opatrzył K. Kumaniecki, Warszawa 2003, s. 82.

${ }^{12}$ Plutarch, Żywoty równoległe, t. 2, przekł. K. Korus, L. Trzcionkowski, Warszawa 2005, s. 176 (w cytacie, dla zachowania toku rozumowania Schneidera, nie uwzględniłem koniektury J. N. Madviga).

${ }^{13}$ Pseudo-Ksenofont, Ustrój polityczny Aten, [w:] A. Mączakowa, Wybór źródet do dziejów starożytnej Grecji i hellenizmu, Warszawa 1986, s. 188. 
Z porównania narracji Schneidra z przytoczonymi przez niego faktami źródłowymi, można sformułować expressis verbis cztery postawione przez niego w przywołanym fragmencie tekstu tezy:

1. W Areopagu dominowali zwolennicy pitagoreizmu (m.in. aluzje w Protagorasie).

2. Na mocy prawa Areopag wprowadził uciążliwy system edukacji (Aksiochos).

3. Ów system edukacji budził sprzeciw Ateńczyków (Tukidydes, Plutarch, Pseudo-Ksenofont).

4. W efekcie buntu demosu ateńskiego rada Areopagu została usunięta, a jej system edukacji zniesiony (Pseudo-Ksenofont).

Jeśliby przyjąć tok rozumowania lwowskiego hellenisty, rozdziały historii wychowania w okresie klasycznym należałoby pisać na nowo. $Z$ tego choćby tylko powodu Stanisław Schneider zasługuje dziś na pamięć i wnikliwe studia jego dorobku. A był to zaledwie jeden (choć ważny) przykład jego nowatorskiego myślenia o edukacji i myśli pedagogicznej w klasycznym antyku.

Gwoli ścisłości przyznać muszę, że tezy o pitagorejskim, skodyfikowanym systemie edukacji Areopagu wydają mi się być oparte na błędnych przesłankach i niesłuszne, nie miejsce tu jednak na przedstawienie argumentów w tej sprawie. Tak czy inaczej: czytanie dziś, po stu latach, tekstów Stanisława Schneidra, jest intelektualną przyjemnością, nawet jeśli (a może właśnie dlatego, że) prowadzi do twórczego sprzeciwu wobec jego poglądów. 